\title{
THE IMPLEMENTATION OF HINDU PHILOSOPHY "TRI KAYA PARISUDHA" FOR SUSTAINABLE TOURISM IN MUNDUK VILLAGE, NORTH BALI
}

\author{
Putu Devi Rosalina \\ International Bali Tourism Institute (STPBI)
}

\begin{abstract}
The rapid growth of tourism evokes a tendency of maintaining relationship between the hosts and guests. The harmony of both parties certainly becomes the main pillar in developing sustainable tourism. Consequently, building two-ways understanding could be fostered by implementing local wisdom. This study, therefore, discusses how the revitalization of Tri Kaya Parisudha could lead to the sustainable tourism development in Munduk. The concept of Tri Kaya Parisudha which consists of the purity of 'mind' (Manacika), 'utterance' (Wacika) and 'attitude' (Kayika), is believed to generate the intellectual, emotional, spiritual and creative energies. This study utilizes quantitative-qualitative approach. The questionnaires are distributed through accidental sampling with 4-likert-scale approach; it is then analyzed qualitatively by in-depth interview through purposive sampling. The result shows that Tri Kaya Parisudha is well applied and understood by Munduk residents, as they welcome the tourists which gives positive impact for their revenue. Most of the tourists were very satisfied with their visit with the $74 \%$ satisfaction rate. Furthermore, the implementation could be enhanced through knowledge, language and attitude, which could establish the loyalty and achieved the positive image of the destination, thus Munduk could eventually embrace sustainable tourism.
\end{abstract}

Keywords: Local Wisdom, Sustainable Tourism, North Bali

\begin{abstract}
Abstrak
Pesatnya pertumbuhan pariwisata menimbulkan kecenderungan untuk menjaga kontak antara penduduk lokal dan wisatawan. Keharmonisan hubungan kedua pihak ini tentunya menjadi pilar utama dalam perkembangan pariwisata berkelanjutan. Oleh karena itu, membangun pemahaman dua-arah dapat dibina salah satunya melalui penerapan kearifan lokal. Maka, pe-
\end{abstract}


nelitian ini mendiskusikan tentang bagaimana revitalisasi Tri Kaya Parisudha dapat berujung kepada perkembangan pariwisata berkelanjutan di Munduk. Konsep Tri Kaya Parisudha yang meliputi 'pikiran' (Manacika), 'perkataan' (Wacika) dan 'perbuatan' (Kayika), dipercaya dapat menghasilkan energi intelektual, emosional, spiritual dan energi kreatif. Penelitian ini menggunakan pendekatan kuantitatif-kualitatif secara deskriptif. Kuesioner disebarkan melalui accidental sampling dengan pendekatan 4 skala likert, yang kemudian dianalisis secara kualitatif melalui wawancara mendalam dengan informan melalui purposive sampling. Hasil penelitian menunjukkan bahwa Tri Kaya Parisudha sudah dipahami dan diimplementasikan oleh penduduk Munduk, seiring dengan keterbukaan mereka untuk menyambut turis karena dianggap memberikan dampak positif terhadap pendapatan. Sebagian besar turis, yakni 74\% menyatakan sangat puas akan kunjungan mereka. Implementasi TKP kemudian harus lebih ditingkatkan lagi melalui pengetahuan, bahasa dan sikap, yang kemudian bermuara pada peningkatan loyalitas dan pembentukan citra baik bagi suatu destinasi, sehingga pada akhirnya Munduk dapat terus berpegangan pada pariwisata berkelanjutan.

Kata kunci: Kearifan Lokal, Pariwisata Berkelanjutan, Bali Utara

\section{Background}

Tourism is the leading sector for economic growth in Bali, with the contribution of $49,72 \%$ to its Provincial Gross Domestic Product (Bali Government Tourism Office, 2014). Unfortunately, the encounter between hosts and guests will not always be successful. Maintaining relationship among the host and guests thus becomes inevitable and an important issue. The different cultural background could spark the cultural conflict, which could create notion that tourism is obviously related to the cultural differences. Thus, the wide gap among the hosts' and guests' cultures could elicit conflicts. Boniface (1999:288) emphasized that while cultural conflict may emerge at any level, its inevitable obvious presence is likely to be at the actual scene of the tourist-host encounter.

In order to diminish this conflict, it is the obligation for both hosts and guests to understand each other and keep the social interaction balance, therefore the social contact of tourism will not give a side-effect to one another. The difficulties of maintaining social interaction could be minimized and even eliminated when tourists and hosts are aware of their cultural differences 
(Reisinger \& Turner, 2011). Robinson and Picard (2006:31) further asserted that close interaction between tourists and the locals generates conditions to dispel myths and stereotypes on both sides.

Meanwhile, the hosts seemed to be more fragile than the guests. Just as what Robinson (1999:21) illustrated, that in tourism relatively few prospective tourists seek total immersion in a different culture and few host societies not to adapt wholly to the need of tourists. As a result, the over-exposure of the culture is more likely affected to the host. Smith (1989:266) then emphasized that as a host community adapts to tourism, in its facilitations to tourists' needs, attitudes and values, the host community must become more like the tourists' culture.

Back to Bali, where philosophies are immersed in the every details of its way of life, it is evident for Bali to improve the development of tourism by linking to its philosophy. Beside the well-known Tri Hita Karana philosophy, there is also another local wisdom which concentrates on how we should maintain the harmony among the human being called Tri Kaya Parisudha (TKP) philosophy. According to Bali World Culture Forum in 2011, TKP generates the intellectual, emotional, spiritual and creative energies that in terms of a socio-cultural-religious perspective represents the culmination of truth, spirituality, honesty, work ethics and social integrity.

Overall, this study reveals how TKP could be implemented in the field of tourism, specifically to enhance the understanding of cultural differences between hosts and guests. The essential focus is not only how the hosts could offer best service to the guests, but also how tourists could respect the indigenous culture vice versa. Hence, it mainly discusses about the implementation of Tri Kaya Parisudha in revitalizing tourism at Munduk village, Buleleng Regency, North Bali.

This research used the quantitative and qualitative data. The statistical data, for instance the number of tourists' arrival in Buleleng Regency, were used as the qualitative data. Moreover, 100 questionnaires were distributed using satisfaction scale with 4 scales, from scale 4 until 1 which signifies the 'very satisfied' to 'dissatisfied' responses respectively. Qualitative data was also used and collected through in-depth interview with the informants, including the head of Munduk village, guesthouse owners, guesthouse workers, and the local community whose Tourism-related business, such as souvenirs vendors, travel and transportation and restaurants. The primary data were taken from questionnaires and interview, and also combined with secondary data taken from mass media, internet and statistics from Statistics Indonesia and Bali Government Tourism Office. This research will use Hofstede's Cultural Dimensions, Intercultural Adaptation Theory, Service Quality and Parasuraman Dimensions as the theories 


\section{Tourism Revitalization through Tri Kaya Parisudha}

Tourism becomes the aspect where numerous kinds of culture encounter each other. It is the challenge for stakeholders to cope with increasing cultural diversity in the workplace, and, as the global trend continues which managing cross-cultural issues, will become more priority in tourism industry. Craig and Douglas (2006), argued that culture is no longer a phenomenon defined by geographic or political boundaries because the world is becoming increasingly deterritorialized and penetrated by elements from other cultures. The mobility of tourism insists the international tourists to adapt and engage into a new culture in the destination, whereas the hosts are also exposed by extremely different cultures and enforced to preserve theirs. It then automatically results into cultural contamination, cultural pluralism, and hybridization.

Thus, the competencies of cross-cultural are very necessary to improve the service. Maintaining Balinese culture is paramount, while understanding tourists' culture inevitably cannot be put aside. As culture is the most fragile element to be impacted of tourism, many scholars suggest that the empowerment will be more effective through the culture instead. Culture must be preserved, because it has universal characteristics (Koentjaraningrat, 2005:11). Bali, particularly, has many kinds of philosophies, such as Tri Hita Karana, Rwa Bhinneda, Tri Kaya Parisudha, etc. Cross-cultural propagation of tourism has constructed a bridge of communication and mutual understanding between different cultural communities.

According to Upadeça school textbook in Sulyanthini (2014), TKP is a guidance in well-behaved attitude. Historically, TKP comes from a shibboleth saying "paropakaran punya ya, papa ya, para piadanam" which means three attitudes that needs to be purified (Asmariani, 2012). Literally, TKP is derived from the word Tri which means three, Kaya which means behavior and Parisudha which means purity or spirituality. Thus, TKP means three pure behavior which leads to better social integrity. According to the believers, those three behaviors comprise of manacika or pure mind, wacika or speaking truthfully, and kayika or act piously. If man bases his conduct on this ethics, he will have a rich life in peace without undue friction and pressure (Peters and Wardana in $\mathrm{Yu}, 2015$ ).

This concept is actually inherited from the term Pawongan in Tri Hita Karana as the key for maintaining the harmony of human relationship continuously. More precisely, Kepramareni et al. (2014) added that Manacika means the purification of mind by stop wanting the forbidden stuffs; Wacika, the purification of utterances by stop lying or giving false promises; Kayika, the purification of action by stop committing heinous deeds. This teaching states that pure mind will lead to pure utterance and eventually to pure action. The final state is when mind, utterance and action 
merge into one unified, consistent entity refers to alignment and purity of one's thoughts, words, and actions (Peters and Wardana, 2013).

According to Sarasamuscaya, TKP has been stated specifically on sloka or line number 73 until 78. Sarasamuscaya is an intact holy Hindu scripture which contain divine revelations, and regarded as the equivalent of bible (Forbes, 2007). Recently, TKP became a theme for Bali World Cultural Forum in 2011. This event which coincided with the 33rd Bali Art Festival, was scheduled to take place in several locations throughout the island, from June 11th to 16th 2011 with the theme of "Trikaya Parisudha", Reinventing One Inclusive World in New Spirit of Cultural Creativity.
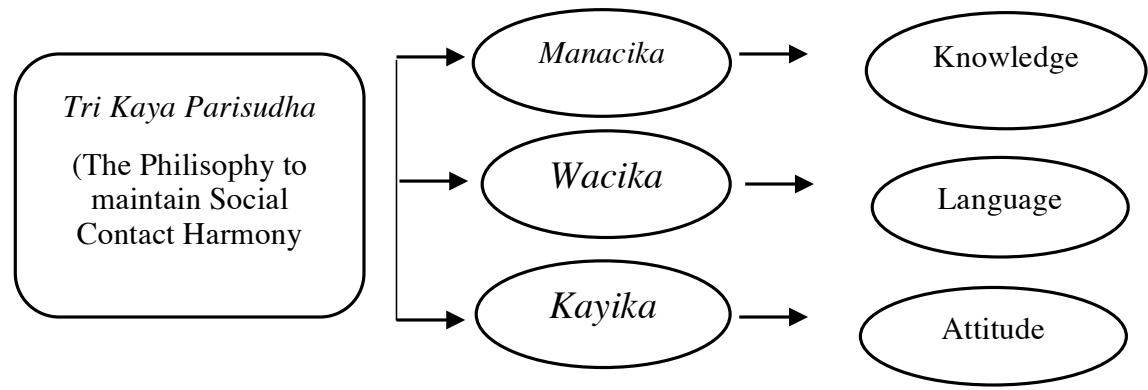

Figure 1: Diagram to Illustrate Tri Kaya Parisudha in Tourism

Source: Sarasamuscaya with additional modification

In tourism, TKP could help to revitalize sustainable tourism especially in social aspect (see Figure 1). In Manacika, the hosts could learn the guests' knowledge in order to prepare in giving better service and hospitality, whereas the hosts are also indirectly encouraged to learn their own culture, so they could explain better to the guests. Wacika concerns more about how to talk and speak. Communicating to people with different background should poses certain respects and politeness, especially through the language. It is then important and necessary to learn more about foreign language; therefore it could maintain proper communication. Politeness and proficiency are two important factors for the language in Wacika. After Manacika and Wacika, Kayika is also a prominent aspect to create the better attitude in tourism. Weiermair (2000) further postulated that cultural proximity or cultural distance can influence not only destination image and familiarity but also tourist attitudes, expectations and perceptions.

\section{Munduk: A Traditional Village Becomes Touristic}

Munduk village is located in Banjar District, Buleleng regency. It is about $60 \mathrm{~km}$ from the centre of Denpasar and $50 \mathrm{~km}$ from Ubud. This village surrounded between borders, such as Gobleg village in the northern part, Gesing village in the southern part, Kayu Putih village in the western part, 


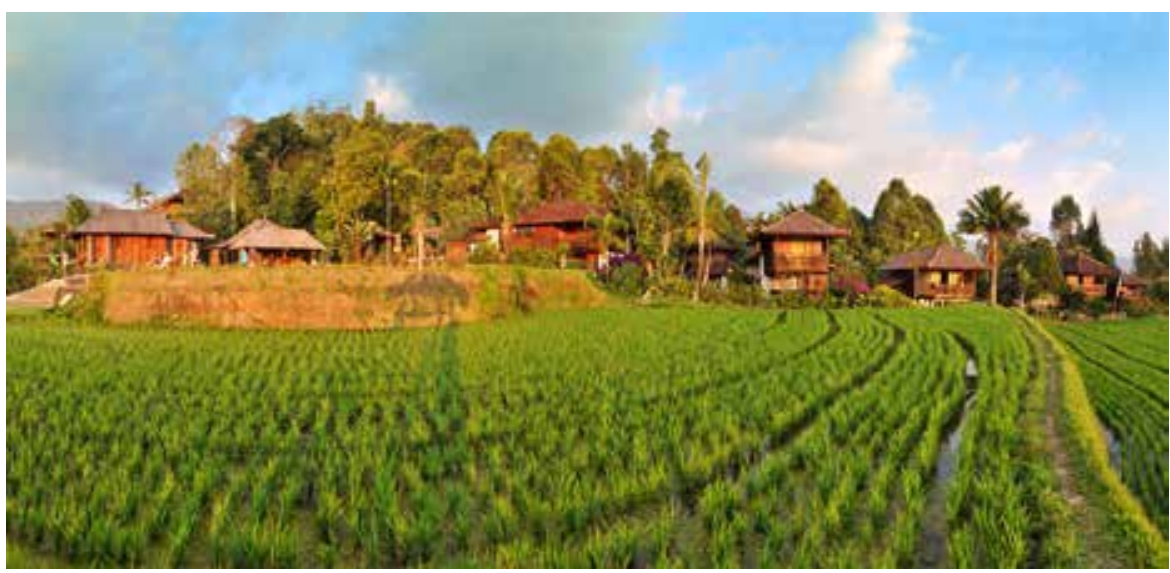

WWW.PURILUMBUNG.COM

Figure 2: Puri Lumbung

while the eastern border is a forest. The total area comprises of $2.710 \mathrm{Ha}$ or $0,48 \%$ of the total area of Bali island. The majority of the area is covered by plantations with the percentage is $40,23 \%$ or $1.090,25 \mathrm{Ha} / \mathrm{m} 2$. These plantations produce the major commodity such as cloves with 31 quintal/ ha in 2013. As it situated on 800-900 m above the sea, it makes Munduk village's temperature is around $20-250 \mathrm{C}$. As an agricultural village, the locals' primary occupations are farmers with totals 3.744 people. in which around $60,57 \%$ of total family in Munduk own the farmland which includes coffee, cloves and cacao. Historically, Munduk has experienced the golden age of coffee farm in 1920 to 1955 (Bagiarta, 2012).

Munduk was actually used as rest break place during the Dutch colonization, while escaping the hustle and bustle of Singaraja. During that time, the Dutch built some guesthouses nearby. It still could be seen as some of the houses in Munduk are still typically in Netherland architecture. Meanwhile, as the capital city then moved from Singaraja to Denpasar, this village is no longer famous for its tourism potential. Furthermore, there are some negative effects such as the migration of young people to work in Denpasar and not developing their own village. The tourism then started to there is one pioneer who had the idea to revitalize this village for tourism benefits. It is Nyoman Bagiarta who initiates the development of tourism in Munduk during the 1990 decade.

Bagiarta started to develop Munduk by building a cottage in 1992 named Puri Lumbung (See Figure 2), perched in the middle of rice fields and clove forests surrounded with a landscape view. It has 16 cottages, consisting of: 12 single and double cottages, 3 family cottages and 1 deluxe family cottage. There were many speakers invited to explain both about advantages and disadvantages of the the tourism development in Munduk. Such international 


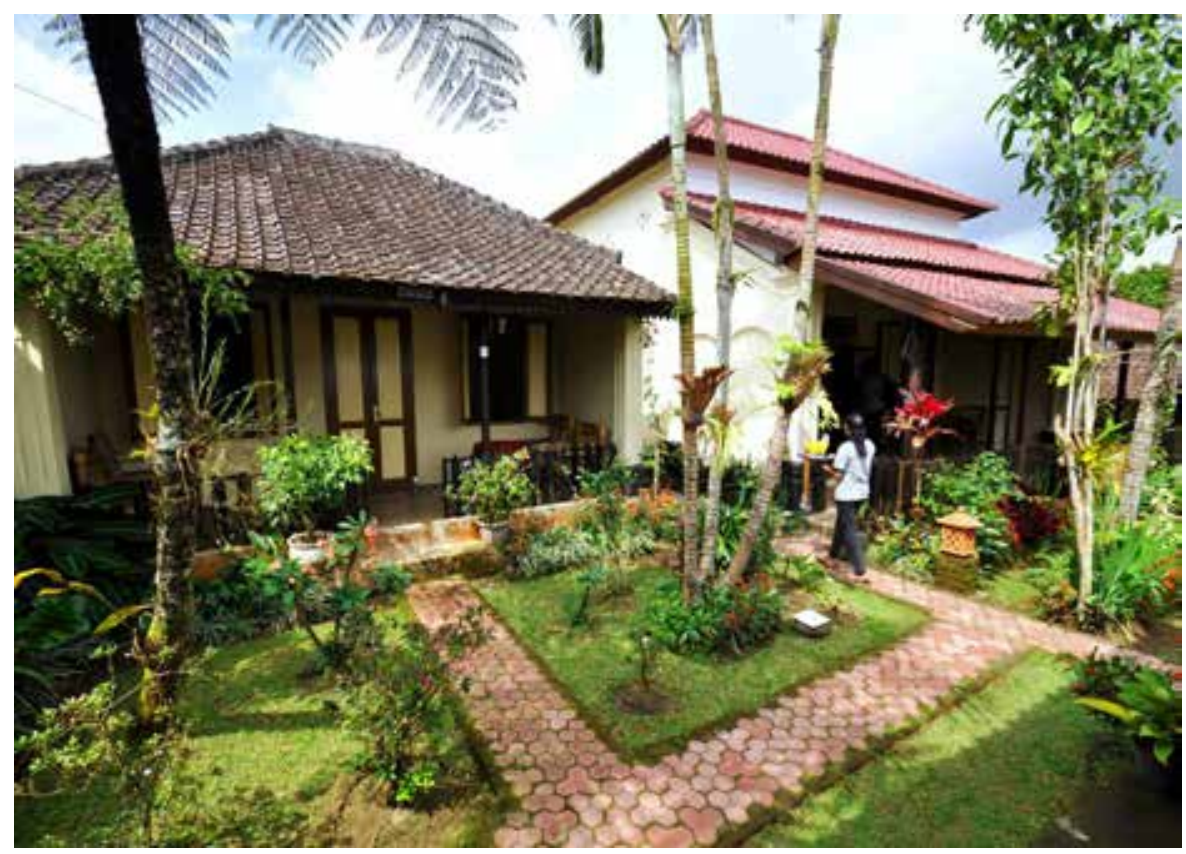

WWW.MEMESURUNG.COM

Figure 3: Meme Surung Homestay

organizations as British Council, Goethe Institute, US Agriculture were also asked to participate in order to spread the information of this event, as well as inviting the competent journalists for the mass media publication

Since tourism in Munduk has been starting to grow, at the same time, there is an urge in order to preserve the sustainability. Tourism in Munduk must grow in line with the preservation of nature, self-awareness of social understanding, and equal economy share. As a matter of fact, Triple Bottom Line needs to be maintained, those are comprising: environment, socioculture and economy. In the environmental aspect, Munduk has several attractions which allow the visitors to take a part in maintaining the nature. One of them is called tamblang or twin sacred mountain springs. Here, the visitors could participate in conserving the water and increasing the quality of life in rural areas. Meanwhile, for socio-culture program, Munduk lets the farmers and young generation to participate actively. Subak or traditional farmers association in Munduk is always being part of this tourism development, their decision and participation is always important. Beside Subak, Munduk also makes an association to manage the destination called Kelompok Sadar Wisata Buana Lestari ${ }^{1}$. This group consists of 40 guides. The mission of this association is to manage any tourism-related issues and matters in Munduk and conducting coordination with government and entrepreneurs and local people. Tourism then seems to attract local people

1 Tourism Awareness Group of Buana Lestari 
to start doing entrepreneurship, there are many tourist facilities start to mushroom, in 2015, for instance: 25 accommodations, 12 restaurants and 1 spa unit which employed mostly Munduk residents. Beside Puri Lumbung that has been described previously, there are also Meme surung (See figure 3) and Aditya homestay. Meme Surung has typically a combination of Dutch and Malay architecture, the nuance is still strongly exuding the nuance of the colonialization era and old Bali. Meanwhile Aditya homestay is situated in the high hill, which the visitors could easily see the view of the villages nearby. The architecture is the combination between modern and traditional.

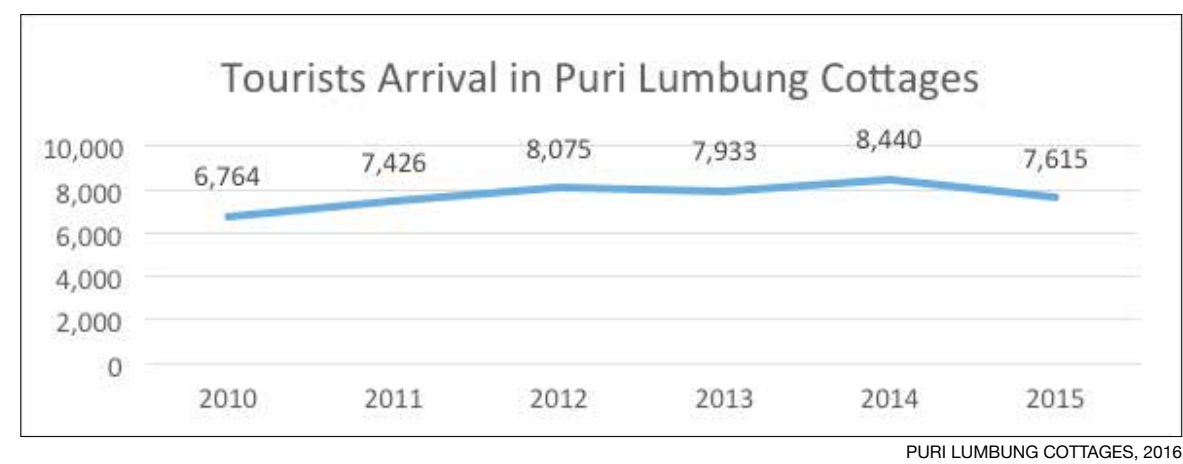

Figure 4: Tourists Arrival in Puri Lumbung Cottages

Munduk has emerged and developed in tourism industry and becoming popular amongst the travelers. Those travelers are mostly from the European countries. The statistics of Puri Lumbung (See figure 4) shows that there is a dynamic development of tourists' arrival. Puri Lumbung received the most tourists in 2014 with total of 8.440 tourist, which increases by $6,39 \%$ compared to the previous year. It is then increasing to become 7.426 tourists, or raising for $9,78 \%$. At the end of 2015 , the number of tourists merely decrease for $9,77 \%$.

According to data from Puri Lumbung Cottages (See figure 5) representing the entire data in Munduk village, it shows that Munduk seems to successfully attracting mostly French tourists with 41,03\% of total tourists visiting Munduk in 2010 are from France, it is then increasing becomes 49,24\% in 2014. Then, following by Netherland for $16,26 \%$ in 2010 . The dramatic increase of Netherland is seen in 2014 compared to previous year in 2013, which becomes $17 \%$. Further, Australia is the third market, yet there was a gradual decline from the last five years, until 6.43\% in 2015. There is also only small percentage of the other nationalities have shown, such as Australian, American and Germany which their share are below than 10\%. Meanwhile, Germany seems to be a prospective market as it is gradually increasing until 2013, it was successfully surpassing Australia and America for the third rank. 


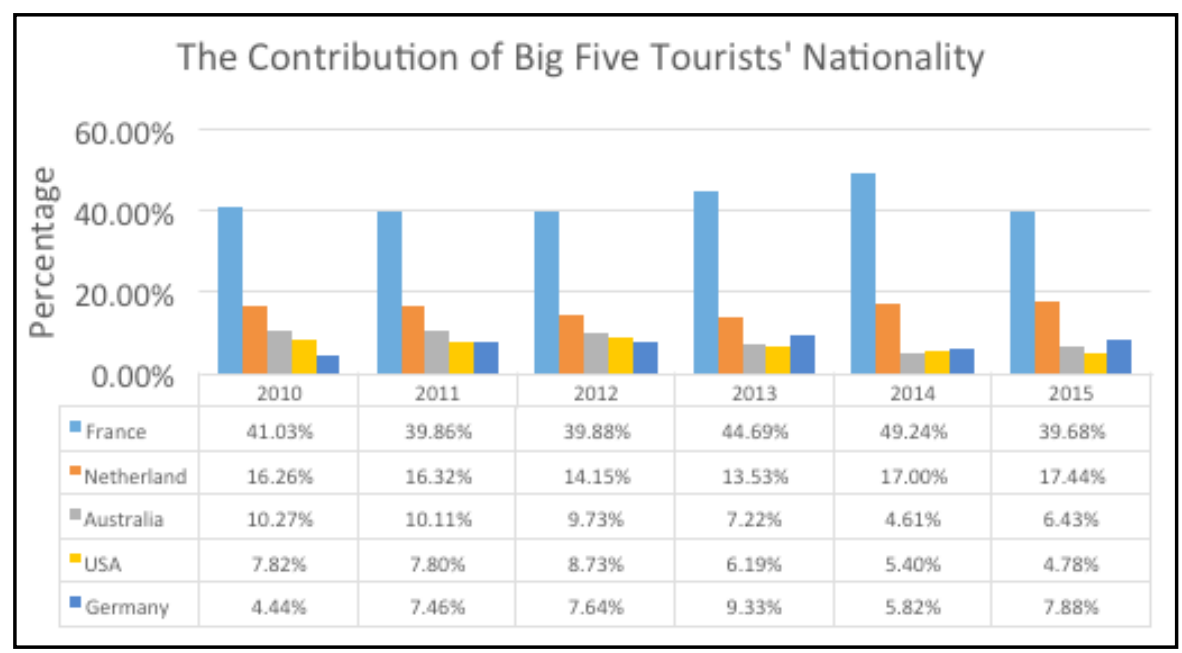

Figure 5. The Contribution of Big Five Tourists' Nationality in Puri Lumbung.

Munduk has achieved several prominent awards. The most prominent one is Tri Hita Karana Award with the level of Gold, Emerald and Platinum. There are also achievements from: tripadvisor and booking.com. The development, marketing and advertising of Munduk does not only depend from the internal participation, but also the external one. Many of satisfied guests published their recommendation to visit Munduk. One of the article below is taken from travel blog by French tourists who visited Munduk in 2014 (See Figure 6).

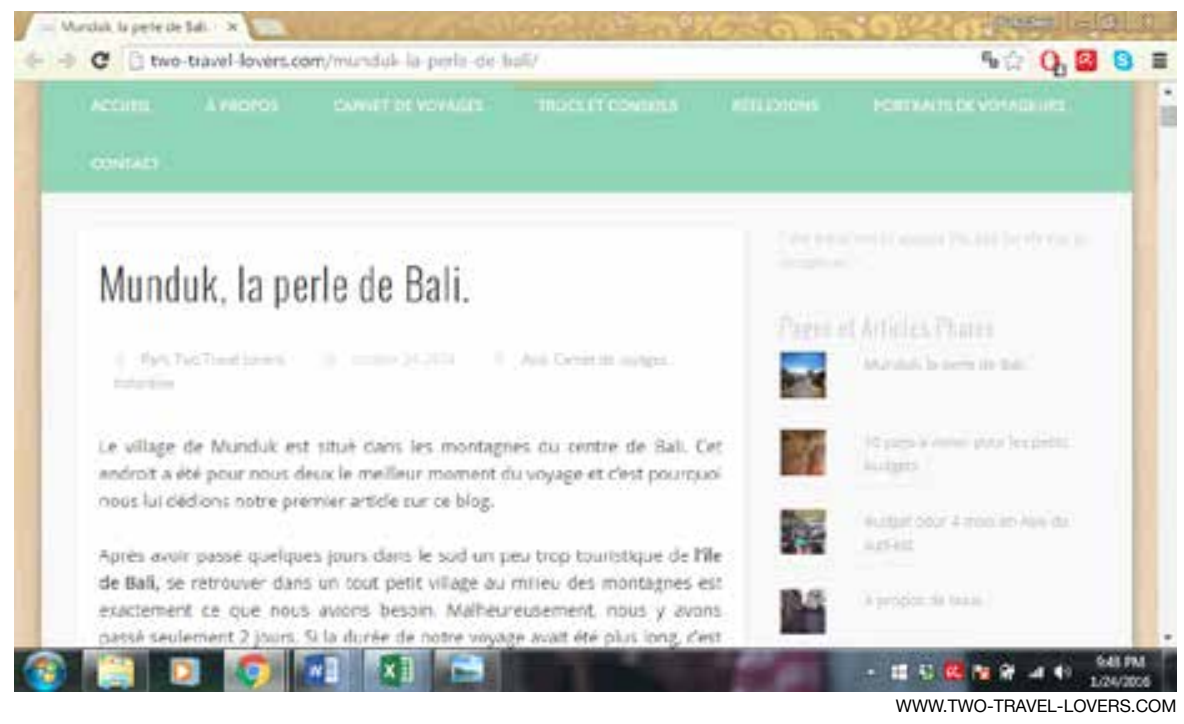

Figure 6. A Travel Blog about Munduk 
The article explained all about Munduk; from how friendly the people are, how tranquil the atmosphere is, until how satisfied the visitors are, while also they have plan to come back one day, as quoted "Si un jour nous retournons à Bali, Munduk sera sans hésiter une de nos destinations."

\section{Hosts and Guests: Munduk Tourism from Two Perspectives}

For centuries, farmers have planted rice in the paddy fields. Bali with its physical beauty and cultural intricacy was the fertile soil for tourists (Forbes, 2007), this statement resembles what occurred in Munduk since in the beginning of 1992. Most of Munduk residents admitted that tourism in Munduk gives positive impact, with the specific main reason such as increasing job opportunity, while also reducing unemployement. However, from tourism group awareness of Buana Lestari put their concerns on how tourism in Munduk is not yet profitable. Further, Jero Bendesa (Head of customary village) emphasized that economically, it is indeed giving the benefit, meanwhile from the perspective of cultures and values, it has to be improved.

The manager of Puri Lumbung cottages also stressed that there are two points concerning the existence of tourism in Munduk: Positive impact and negative impact. The positive ones are: (1) The equal human resource skill, so thanks to tourism development in Munduk, it makes tourism not only centralized in the south; (2) Absorbing more local people to the workforce and decreasing urbanization; (3) Increasing local people revenue directly or indirectly; (4) More business and job opportunities are available; (5) More new destinations are discovered; and (6) Encouraging more young entrepreneurs. Meanwhile, the negative impacts of tourism are comprising: jams, rubbish, increasing price, more outsiders come to Munduk, the threats to the natural resources, mindset change from agricultural into trade, more investors will come which leaves certain anxiety of more investor control, not locals, and the acculturation which may affects local lifestyle.

Furthermore, concerning the skills and capabilities in giving service, professionalism is indeed a priority. The local people, as well as with the government and tourism awareness association in Munduk have done several methods to increase skills of human resources, such as training, communication forum, self-learning, marketing the tourist destinations, and lastly evaluation periodically. The trainings include Balinese dance, playing Gamelan, teaching cooking class, practicing spa, learning English and many more. One restaurant owner also said that they are collaborating with Bali Tourism Institute Nusa Dua (Sekolah Tinggi Pariwisata Nusa Dua) and other professionals. Local people in Munduk also hold a regular forum to discuss several issues such as sanitary, health, security and hospitality for the tourists in their village. Many of them are also encouraged to learn by 
themselves thorugh internet or consulting the dictionary.

On the other hand, from guests' point of view, from 100 samples, it is obtained that 43 are men and 57 women tourists who visit Munduk. The characteristics were viewed from the nationality, the majority is from Europe with the percentage of $67 \%$ out of total respondents, and France is dominating the market, while Netherland is on the second position. Then, followed by the United States, Australia and Asia with the percentage of $12 \%$, $10 \%$ and $11 \%$ respectively.

Besides, based on the characteristic of the tourists, Munduk seems to attract more adventurous young tourists, with the age range between 2635 as the majority. Classified based on their occupation, it is observed that most tourists are professional with the percentage of $36 \%$, then followed by student and executives with the percentage of $17 \%$ and $12 \%$ respectively. It means that, from the generalization of the visitors, that Munduk is mostly visited by well-educated people who seek for the tranquility away from their daily activities Next, when classified based from their consorts, half of them is accompanied by either friends/relatives or with families, the percentage is $45 \%$ and $41 \%$ respectively. However, only $14 \%$ who preferred to do solo travel in Munduk. Then, for the length of stay, the average is 3.04 days, with the minimum is two days.

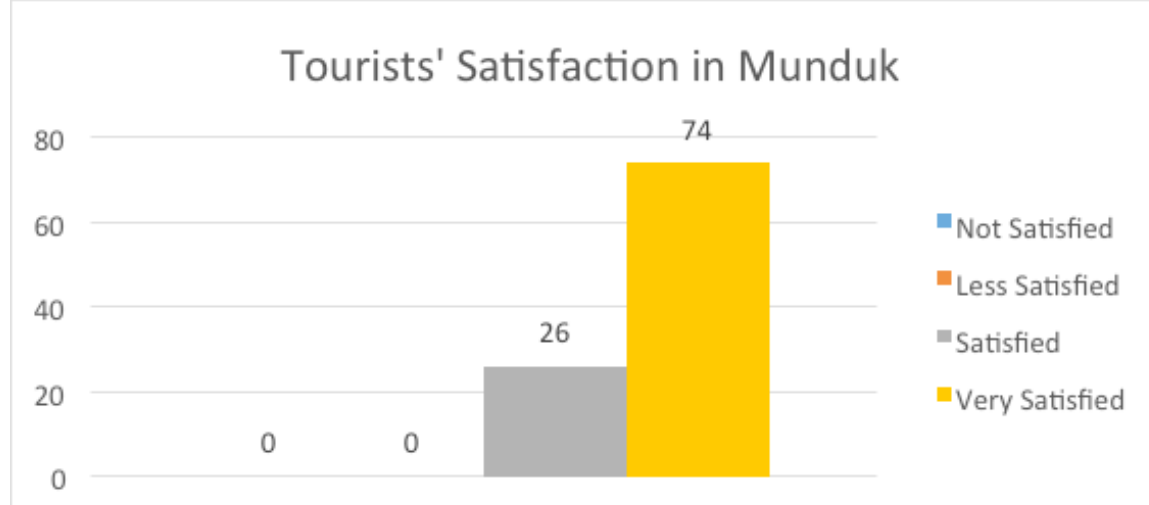

Figure 7: Tourists' Satisfaction

SURVEY, 2016

Munduk has strongly attracted first-timer than repeater, it is revealed from data that there $86 \%$ who visited Munduk for the first time, yet only $4 \%$ for the second time and $10 \%$ for the third time or more. The level of satisfaction is considered high as $74 \%$ of tourists who feel very satisfied after visiting Munduk and only 26\% who feel satisfied (See figure 7).

Beside tourist attractions, tourist activities are also offered which includes the activities inside the homestay or outside. During their stay in 
the homestay, the tourists were pampered by numerous cultural activities, such as traditional massage, dancing class, traditional Balinese musical instrument, bamboo instrument making, weaving class, pajegan bunga and $b_{u a h^{2}}$ class, knitting class, cooking class and spinning top games. The tourists also could learn Indonesian and Balinese language. Medical and spiritual tourist attractions also becomes favorite, such as spiritual discussion, hatha yoga, herbal medicine class. Munduk also offered agrotourism such as the processing and refreshment of traditional Bali Coffee and clove harvesting. Whereas outside the homestay, the tourists could do trekking and bicycling with the tour guide.

In an area of nascent tourism, problems in the host-guest relationship seem certain to occur (Smith, 1989:150). Cross-cultural competencies are very necessary to improve the service. Nowadays, Bali is experiencing globalization while also has been struggling to preserve their cultural diversity. Maintaining Balinese culture is paramount, while understanding tourists' culture cannot be put aside inevitably. It was generally assumed by some researchers and tourism practitioners that tourist holiday experience and satisfaction is determined by material and physical needs and derives from operational buying motives such as the level of service provision (Reisinger \& Turner, 2011). Thus, by understanding cross-cultural diversity could improve the level of satisfaction experienced by tourists.

According to the collected data, it is found that all of the stakeholders agreed that both tourists and locals must have mutual understanding. One of the stakeholders as a guide, even mentioned that local wisdom must be applied at the very first conduct. The souvenir shopkeepers also added that the tourists must not be enforced to buy their goods, because this could lead to inconvenience. The satisfaction of tourists could influence their willingness to revisit. There are $66 \%$ of tourists who choose to have a plan in revisiting Munduk, only 34\% who said no. Those who said 'Yes' have a reason that Munduk has been surrounded by well-preserved nature, some of them also admitted the healthy living and natural ecosystem. Surprisingly, 99\% of respondents were willing to recommend Munduk.

As a matter of fact, cross-cultural satisfaction means reaching the satisfaction for both side, including guests and tourists. Tourism is about accomplishing the needs between these two different poles, maintaining the balance between the desire of the tourists and the preservation of the local culture and pure nature. Indeed, the hosts are always enforced to adapt in order to serve better service to the tourists. In the majority of cases, local people are subjected to a steady stream of changing faces, while tourists vary their destinations with ever-changing frequency (Smith, 2003:53). Thus,

2 Pajegan bunga is the Balinese flower arrangement, usually carried during the ceremony in the temples. Pajegan buah is similar as pajegan bunga, yet it contains fruits. 
Munduk has to be aware and prepared not only to satisfy tourists but also concerning the satisfaction within, which means to all stakeholders and local community. It could be done by improving their prosperity which is generated by tourism and balancing the market price, so there will be no unhealthy war price. An annual, or even monthly meeting has also been done in order to diminishing conflict as minimum as possible. This could shape tourism to be developed in sustainable way.

\section{Conclusion}

Bali re-emerges one philosophy that would be applicable in term of guest-host cross-cultural encounter. Tri Kaya Parisudha which simply means three pure conducts include: Manacika or pure mind, Wacika or pure utterance, and Kayika or pure attitude. In the implementation in tourism, it is necessary to establish good image of local people by improving better knowledge of both local culture and foreign culture, embracing better language to communicate and building proper attitude towards the guests. These three basic concept becomes a foundation to help the revitalization in Munduk's tourism development.

The mutual understanding among hosts-guests could also attributed to increase the level of satisfaction. Munduk successfully maintained tourists' satisfaction with nearly almost all of the tourists feel comfortable, relaxed and satisfied spending their vacation. It is not only due to the nature and different culture, but also the hospitality of local people. in the end, this satisfaction would eventually affect to loyalty, which could encourage the tourists to recommend this site to another prospective guests. Satisfaction is the special key to creating image and advertising destination which eventually could create positive chain to maintaining sustainable tourism, especially in the social aspect.

\section{Acknowledgement}

My immense gratitude goes to my thesis supervisor, Madame Sylvine Pickel-Chevalier for her patience, warm guidance of encouragement, and her directions. I also would like to express my gratitude to Prof. Dr. I Nyoman Darma Putra, M.Litt, who has encouraged me, from achieving the scholarship until the process of conducting the research through his wise and helpful suggestions. This accomplishment would not have been possible without them.

\section{Bibliography}

Asmariani, A.A.R. 2012. Tri Kaya Parisudha Sebagai Kontrol Sosial Perilaku Remaja dalam Kehidupan Bermasyarakat di Era Globalisasi dan Modernisasi. Available from: http://download.portalgaruda.org/article.php?article= 
117632\&val=5416, downloaded on April 302016

Badan Pusat Statistik Provinsi Bali. 2015. Bali dalam Angka. Available from: bali. bps.go.id on January 22016

Bagiarta, I Nyoman. 2014. Short History of Munduk Village. Available from: http:// nagaloka-foundation.org/wp-content/uploads/2015/o9/Short-History-ofMunduk-Village-by-Pak-Bagiarta-J-3.pdf on January 142016

Boniface, Priscilla. 1995. Managing Quality Cultural Tourism. London: Routledge

Budarma, I Ketut. 2011. “Syncretism Between Tourists' and Local Culture: the Impact of Tourism on Balinese Culture, Economy and Environment”. Thesis. Angers: Université d'Angers

Craig, C. S. and Susan P. Douglas. 2006. «Beyond national culture: implications of cultural dynamics for consumer research.» In International Marketing Review, Vol. 23: 3, pp.322 - 342. Available from: http://www.emeraldinsight.com/. Downloaded on September 42015

Dinas Pariwisata Provinsi Bali. 2016. Statistik Pariwisata Bali. Denpasar: Dinas Pariwisata Provinsi Bali

Forbes, C. 2007. Under the Volcano: The Story of Bali. Melbourne: Black Inc

Hitchcock, Michael \& I Nyoman Darma Putra. 2007. Tourism, Development and Terrorism in Bali. Burlington: Ashgate Publishing Company

Hofstede, G. 2001. Culture's Consequences: Comparing Values, Behaviors, Institutions and Organizations across Nations. London: Sage

Kepramareni et al. 2014. Sekala and Niskala Accountability practices in the clanbased organization MGPSSR in Bali, Indonesia. Scientific Research Journal (SCIRJ), Volume II, Issue II, February 2014. Available from: http://www.scirj. org/papers-0214/scirj-P021497.pdf, Downloaded on April 12016

Koentjaraningrat. 2005. Pengantar Ilmu Antropologi. Jakarta: PT Rineka Cipta

Peters, J. H., \& Wardana, W. 2013. Tri hita karana: The spirit of Bali. Jakarta: Kepustakaan Populer Gramedia.

Reisinger, Yvette \& Lindsay W. Turner. 2011. Cross-Cultural Behaviour in Tourism: Concepts and Analysis. New York: Routledge

Robinson, M. \& Picard, D. 2006. Tourism, Culture, and Sustainable Development. Division of cultural policies and intercultural dialogue, Culture Sector, UNESCO. Smith, V. L. 1989. Hosts and guests: The Anthropology of Tourism. Philadelphia: University of Pennsylvania Press

Sulyanthini, Luh Putu. 2014. Geguritan Sri Sedana Analisis Struktur dan Fungsi. Available from: http://ojs.unud.ac.id/. Downloaded on April 172016

Weiermair, K. (2000), “Tourists' perceptions towards and satisfaction with service quality in the cross-cultural service encounter: implications for hospitality and tourism management”, Managing Service Quality, Vol. 10 No. 6, pp. 397-409.

$\mathrm{Yu}$, Alan James. 2015. On Moral Imagination and Indigenous Wisdom: How Leaders Approach Moral-Ethical Tension in Post-Modern Bali. Available from: http://digital.sandiego.edu/. Downloaded on April 162016 


\section{Writer Profile}

Putu Devi Rosalina is a postgraduate student in Tourism Studies, Udayana University. During her study, she achieved a scholarship "Indonesia-France Double Degree" which allows her to get an opportunity learning Tourism and Hospitality Management in Université d'Angers for one academic year. She now works as an English Teacher in STPBI (International Bali Tourism Institute) and Indonesian Language Teacher in Alliançe Francaise de Bali. Whilst studying in France, she had an experience teaching Indonesian language and culture for bachelor students in Université d'Angers for 16-hours-course of L'innitiation à la Langue et Culture Indonésienne. Email: putudevi31@gmail.com 